Yngve Antonsen

UiT Norges arktiske universitet

Gregor Maxwell

UiT Norges arktiske universitet og Jönköping universitet

Kristin Emilie W. Bjørndal

UiT Norges arktiske universitet

Rachel Jakhelln

UiT Norges arktiske universitet

DOI: http://dx.doi.org/10.5617/adno.7918

\title{
«Det er et kjemperart system!» - spesialpedagogikk, tilpasset opplæring og nyutdannede læreres kompetanse
}

\begin{abstract}
Sammendrag
De nye femårige grunnskolelærerutdanningene i Norge skal utdanne lærere med fagfordypning og forskningsbasert kunnskap. Disse lærerne skal kunne tilpasse opplæringen til den enkelte elev og integrere spesialundervisning i grunnskolen. Studiens forskningsspørsmål er: Hvordan erfarer nyutdannede grunnskolelærere at den formelle lærerkompetansen fra en integrert femårig grunnskolelærerutdanning samsvarer med deres behov for kunnskap om tilpasset opplæring og spesialpedagogikk i yrkesstarten? Studien er basert på kvalitative intervjuer med 43 nyutdannede lærere fra de tre første grunnskolelærerkullene med femårig integrert masterutdanning for skolens trinn 1-7 og 5-10 fra UiT Norges arktiske universitet. Undersøkelsen inngår i det longitudinelle forskningsprosjektet «Relevant masterutdanning for grunnskolelærere». Analysen av data er basert på en temasentrert analysestrategi i NVivo12. Resultatene viser at de nyutdannede lærerne opplevde utfordringer med å tilpasse opplæringen for en sammensatt elevgruppe, og spesielt for elever med behov for særskilt tilrettelegging. De nyutdannede lærerne erfarte at de manglet kunnskap og ferdigheter til å arbeide med atferdsproblemer og bestemte diagnosegrupper. De manglet også kunnskap om hvordan det eksterne spesialpedagogiske støtteapparatet fungerer, og hvordan og når de skal melde inn tiltak. De nyutdannede tilegner seg spesialpedagogisk kompetanse ved å teste ut egne ideer, eller de bygger på råd fra kolleger. Enkelte deltar på kurs eller veiledning fra PPT, BUP eller andre aktører om temaer som individuelle opplæringsplaner eller diagnoser. Den erfaringsbaserte læringstilnærmingen styrker etablert og kritisert tenkning om spesialpedagogikk og viderefører et system som ikke fungerer (Nordahl et al., 2018). Nyutdannede lærere trenger mer kunnskap om inkluderende pedagogikk og relasjonell tenkning i utdanningen.
\end{abstract}

Nøkkelord: femårig grunnskolelærerutdanning, nyutdannede lærere, spesialpedagogikk, tilpasset opplæring, relasjonell tenkning, inkluderende pedagogikk 


\title{
“It’s a very strange system!” - Special education, adapted education, and newly qualified teachers' competence
}

\begin{abstract}
The new Norwegian five-year primary and lower secondary school teacher education prepares teachers with increased subject-specific and research-based knowledge. These new teachers should be able to adapt teaching to individual students and integrate special education approaches. The research question is: How do newly qualified teachers experience their formal teacher competences from a five-year integrated master's programme compared with their need for knowledge about adapted and special education at career-start? The study is based on qualitative interviews with 43 newly qualified teachers from the first three cohorts of a five-year integrated master's teacher education programme at UiT The Arctic University of Norway. The study is part of the longitudinal research project "Relevant master education for school teachers". Data are thematically analysed in Nvivo12 with results showing that new teachers experienced challenges in adapting teaching to all students, especially to students with needs of additional support. The new teachers found that they lack the competence to work with behavioural problems and particular diagnostic groups. They felt that they lack expertise on how external specialist support systems work and how and when to report concerns. Newly qualified teachers acquire special education competence by testing out their own ideas or based on advice from colleagues. Some also attend courses or seek guidance from support services on topics such as individual plans or diagnoses. The experiencebased learning approaches taken by new teachers strengthen established and criticised thinking about special education and perpetuates a dysfunctional system. Newly qualified teachers need more knowledge about inclusive pedagogy, adapted education, and relational thinking in education.
\end{abstract}

Keywords: primary and lower secondary school teacher education, newly qualified teachers, special education, adapted education, relational thinking, inclusive pedagogy

\section{Innledning}

Norge, som mange andre medlemsland i The Organisation for Economic Cooperation and Development (OECD, 2019), har sett en økning i antall barn som mottar tradisjonell spesialundervisning i skolen (Markussen, Strømstad, Carlsten, Hausstätter \& Nordahl, 2007). Tallene har stabilisert seg de siste fire-fem årene på rundt 8 \% (Statistisk sentralbyrå, 2019, s. 10). Ifølge opplæringsloven (1998, $\S 5-1)$ gis retten til spesialundervisning til «elever som ikke har eller kan få tilfredsstillende utbytte av den ordinære opplæringen». Innholdet i det spesialpedagogiske tilbudet skal ta utgangspunkt i den enkelte elevs utviklingsutsikter. Mens det norske systemet internasjonalt er ansett som inkluderende, er det likevel nasjonalt fokus på hvordan alle elever skal få best utdanning (Fasting, 2013). Ekspertgruppen for barn og unge med behov for særskilt tilrettelegging (Nordahl et al., 2018) konkluderer med at systemet for spesialpedagogisk støtte i norske skoler er lite funksjonelt og skaper ekskluderende spesialundervisningssystemer. 
Et stort antall barn får støtte fra personell som mangler passende kvalifikasjoner og kompetanser (Nordahl et al., 2018).

Nordahl et al. (2018, s. 8) foreslår følgende prinsipp i skolen: «Alle barn og unge med behov for særskilt tilrettelegging i barnehage og skole skal møte lærere med relevant og formell pedagogisk kompetanse.» Lærernes kompetanse er en nøkkel for å fremme tilpasset undervisning og spesialundervisning i skolen (Nordahl et al., 2018). En kritikk mot manglende spesialpedagogisk kompetanse i lærerutdanningen for å gjennomføre tilpasset opplæring (TPO) ble først tatt opp av Gjessing (1967) og har vært en pågående diskusjon. Norske rektorer har også i en rapport fra Riksrevisjonen (2006) poengtert bekymringer om læreres kompetanse for å fremme TPO.

Et mål med å implementere den nye femårige grunnskolelærerutdanningen i Norge er å utdanne nye lærere som har økt forskningskunnskap og mer dybdekunnskap i færre undervisningsfag. Intensjonen er økt lærerprofesjonalitet, som innebærer at lærerne skal bygge sin profesjonsutøvelse på forsknings- og erfaringsbasert kunnskap (Kunnskapsdepartementet, 2016a, 2016b). Målet er at de nyutdannede evner å observere, analysere og utvikle eget arbeid basert på teori (Sætra, 2018). Didaktikk er sterkere integrert i fordypningsfagene, og det tradisjonelle pedagogikkfaget har fått mindre plass. De nye lærerne skal bruke virkemiddelet TPO med mål om å integrere spesialundervisning med generell undervisning i klasserommet (Velsvik Bele, 2010).

Det er behov for norsk forskning som undersøker hvordan lærere med femårig grunnskolelærerutdanning selv erfarer sin egen lærerkompetanse for å arbeide med TPO og spesialundervisning. Lærerkompetanse er definert som «en integrert enhet av å gjøre, å vite, å reflektere og å være. Å gjøre viser til praktiske ferdigheter, mens å vite refererer til kunnskaper innen pedagogiske fag og emner, så vel som innen fag og emner som det undervises i i grunnskolen» (Brekke, Bjarnadóttir \& Søndenå, 2008, s. 10). Ut over dette vektlegges lærerens evne til refleksjon over egne pedagogiske aktiviteter og egne oppfatninger i både klasse- og skolekontekst. Lærerkompetanse innebærer derfor kunnskaper og ferdigheter og et potensial til å anvende disse i aktuelle situasjoner og ulike kontekster. Lærerkompetanse vil derfor inkludere ulike former for spesialpedagogisk informasjon som lærerne har ervervet seg og systematisert i utdanning og yrkespraksis (Cardona, 2009). Spesialpedagogisk kunnskap innbefatter også å vite hvordan man kan tilegne seg nødvendig informasjon, og hvor man kan få hjelp med spesialpedagogiske spørsmål. Med ferdigheter kan vi forstå anvendelse av praktiske spesialpedagogiske verktøy til undervisning og for å samhandle med støttesystemer.

Denne kvalitative, longitudinelle intervjustudien undersøker nyutdannede grunnskolelæreres møte med yrkets utfordringer og krav til spesialpedagogikk og TPO. Problemstillingen er: Hvordan erfarer nyutdannede grunnskolelærere at lcererkompetansen fra en integrert femårig grunnskolelcererutdanning samsvarer 
med deres behov for kunnskap om tilpasset opplering og spesialpedagogikk $i$ yrkesstarten?

Artikkelen er strukturert slik: Først presenterer vi tidligere forskning om TPO, og deretter redegjør vi for et teoretisk rammeverk om inkluderende pedagogikk og relasjonell tenkning. I metodedelen redegjør vi for datagrunnlag og analyse. Resultatene oppsummerer funnene fra analysen. I diskusjonen drøftes funnene i relasjon til tidligere forskning. Konklusjonen oppsummerer våre funn og antyder nye forskningsbehov.

\section{Tilpasset opplæring (TPO)}

TPO er en sentral del av den norske utdanningsfilosofien og lovverket (Opplæringslova, 1998, § 1-3) og vektlegger skolens rolle i å bidra til et sosialt inkluderende og støttende samfunn (Mordal \& Strømstad, 2005). Generelt har TPO blitt ansett som en positiv faktor for å fremme og forbedre inkludering i norske skoler (Maxwell, 2017). Likevel er TPO et politisk verktøy, og innholdet forandres på bakgrunn av det politiske landskapet og styringsdokumenter (Jenssen \& Lillejord, 2009). Ifølge Bachmann og Haug (2006), som gjorde en gjennomgang av norsk forskningslitteratur knyttet til TPO, finnes det en smal og en bred forståelse av TPO. Den smale forståelsen handler om TPO som bruk av konkrete og spesifiserte metoder, tiltak og organisering av undervisning og opplæring for elever. Tiltakene er pragmatiske av natur og settes inn mot enkeltelever, og de kan registreres av en lærer eller et støttesystem (Bachmann \& Haug, 2006, s. 7). TPO i en vid forståelse er et pedagogisk grunnlag for å gi alle elever et så godt læringsutbytte som mulig i skolens virksomhet (Haug, 2004), noe som innebærer å forsterke elevenes opplevelse av samhold, engasjement og deltakelse (Bakke, 2017). For å lykkes med TPO kreves det sosial integrering så vel som faglig integrering (Flem \& Keller, 2000).

I 2000-årene ble spesialpedagogiske støtteressurser brukt noe vilkårlig for å gi støtte til elever i fagene norsk, engelsk og matematikk, uavhengig av årsaken eller grunnlaget (Markussen et al., 2007, s. 92). Tilsvarende ble det også utviklet en kultur hvor ekstra støtteressurser ble brukt for å få urolige elever ut av klasserommet (Markussen et al., 2007, s. 97). For å få ekstra ressurser ble elevene ofte gitt en diagnose, noe som også var relatert til juridiske og økonomiske årsaker (NOU, 2003:16). Fasting, Sarromaa Hausstätter og Turmo (2011) argumenterer for at den spesialpedagogiske praksisen har bidratt til et ekskluderende miljø som inneholder elementer som går på tvers av målsetninger og aspirasjoner om integrering, inkludering og TPO. Ifølge Nordahl et al. (2018) er støttesystemet fortsatt organisert slik at elevene som mottar støtte, opplever manglende fellesskap med andre elever. Nordahl et al. (2018) utdyper videre at det tar for lang tid å treffe tiltak, og at spesialpedagogisk støtte gjerne kommer inn når en elev er midtveis i sin grunnskolekarriere, noe som er i strid med prinsipper i 
opplæringsloven om tidlig innsats (Opplæringslova, 1998, § 1-4). Problemene følger av strukturene og individets rettigheter i det nåværende systemet, hvor spesialistene bruker for mye av sin tid på byråkratisk administrasjon, i stedet for å utnytte sin spesialkompetanse i skolen sammen med elevene (Nordahl et al., 2018). Nordahl et al. (2018) møter kritikk, spesielt fra det spesialpedagogiske fagmiljøet, av forslaget om å fjerne enkeltelevers rett til spesialundervisning (Uthus, 2018).

Utfordringen med å redusere spesialundervisning i skolen er ikke bare begrenset til regjeringsrapporter, byråkrati og utdanningssystemet i Norge, men er også knyttet til utdanning, hvor de ulike fagområdene ikke er integrert på en funksjonell måte (Skogen, 2014, s. 85). Spesialpedagogikk er enten et eget utdanningsfag eller kan velges som et av fagene i lærerutdanningen, men er i liten grad inkludert i den nye lærerutdanningen for de studentene som velger andre undervisningsfag.

\section{Inkluderende pedagogikk og relasjonell tenkning}

Internasjonalt har det vært lite fokus på nyutdannedes lærerkompetanse for å arbeide inkluderende med elever (Florian \& Spratt, 2013). En studie i Skottland (Florian \& Spratt, 2013) undersøkte hvordan nyutdannede lærere forstår og anvender begrepet inkluderende pedagogikk (inclusive pedagogy). Ifølge Florian og Spratt (2013) er inkluderende pedagogikk definert av tre prinsipper: 1) Forskjell må redegjøres for som et essensielt aspekt av menneskelig utvikling i enhver begrepsliggjøring av læring, 2) Lærere må tro (kan overbevises om) at de er kvalifiserte og i stand til å undervise alle barn, og 3) De profesjonelle må kontinuerlig utvikle kreative nye måter å samarbeide med andre på (Florian \& Spratt, 2013, s. 124). Florian og Spratt (2013) har et læringssyn som er dynamisk og endringsfokusert, hvor alle elever som får riktig støtte, kan lære, og hvor alle elevene har en likeverdig plass i en læringssituasjon.

Florian og Spratts (2013) studie viser hvordan nyutdannede lærere med innsikt i relasjonell tenkning utviklet en inkluderende pedagogikk som tok hensyn til enkelteleven og mangfoldet i klasserommene. Relasjonell tenkning er sentral i utviklingen av en pedagogisk praksis som integrerer læring og trivsel (Dalkilic \& Vadeboncoeur, 2016). Florian, Hawkins og Rouse (2017) påpeker at en lærers evne til å handle relasjonelt kan ha betydning for å utvikle en mer inkluderende pedagogikk. En relasjonell tenkning og tilnærming til spesialpedagogikk og TPO flytter oppmerksomheten fra instrumentell tenkning og bruk av metoder, konkrete oppskrifter og definerte løsninger for arbeidet til «a more nuanced and relational way of considering how schools can respond to difference is needed» (Florian et al., 2017, s. 27). For lærerne innebærer en relasjonell tilnærming at de stiller spørsmål ved sine antakelser, og øker egen innsikt i forholdet mellom elevatferd og underliggende tanker og følelser. Aspelin (2014, s. 240) bemerker at et 
nøkkelattributt i å utvikle en slik relasjonstilnærming, og å fremme TPO, er lærerens evne til å forstå den enkelte elevs perspektiv. Relasjonell tenkning fordrer en inkluderende pedagogikk som skal bidra til et utdanningssystem som fremmer elevens mulighet til å være aktiv i egen læring (Dalkilic \& Vadeboncoeur, 2016).

En svakhet med den relasjonelle tenkningen er at begrepet er tvetydig. Denne tvetydigheten kan skyldes at relasjonell tenkning kobles til sosial ideologi og menneskesyn om likebehandling av alle mennesker. Begrepet tar slik utgangspunkt i generelle prinsipper for å fremme integrasjon, inkludering og normalisering. Relasjonell tenkning gir et dilemma som også er treffende for TPO: å tilby like utdanningsmuligheter for alle elever og samtidig gi individuell skreddersydd utdanning (Bakke, 2011).

\section{Metode}

\section{Case}

Studien er basert på et kvalitativt design innenfor et konstruktivistisk og fortolkende forskningsparadigme (Crotty, 1998). Studien er en del av forskningsprosjektet «Relevant masterutdanning for grunnskolelærere» (RELEMAST) (Jakhelln, Bjørndal \& Stølen, 2016), som følger de tre første grunnskolelærerkullene (kull 2010, 2011 og 2012) med femårig integrert masterutdanning, inkludert både første til syvende trinn (heretter 1-7) og femte til tiende trinn (heretter 5-10) fra UiT Norges arktiske universitet (Jakhelln et al., 2016). Utdanningen begynte i 2010 som den første utprøving av en femårig integrert masterutdanning for grunnskolelærere og bidro med føringer for de nye nasjonale grunnskolelærerutdanningene 1-7 og 5-10 (heretter GLU) fra 2017.

I de undersøkte grunnskolelærerkullene ble temaene spesialpedagogikk og TPO tatt opp i det andre året i studiet i et 20 studiepoengs emne for 1-7 og et tilsvarende for 5-10. Ifølge studieplanene (Universitetet i Tromsø, 2010a, 2010b) skal emnet gi studentene en basiskompetanse i pedagogiske problemstillinger knyttet til barns utvikling og læring individuelt og i samspill med andre. Sosialog spesialpedagogiske utfordringer gjennomgås med vekt på TPO samt forebygging og håndtering av atferdsproblematikk og mobbing. Emnene skulle blant annet gi kunnskap om forholdet mellom tilpasset opplæring og spesialundervisning. For 1-7 var et av ferdighetsmålene at studentene skulle gjøre rede for og drøfte ulike forutsetninger for å utarbeide en individuell opplæringsplan (IOP). I 5-10 skulle emnet gi kunnskap om saksgang ved vurdering av behov for spesialundervisning og utarbeidelse av IOP. For begge trinnene ble temaene fulgt opp i praksisperioden i det andre året i utdanningen (Universitetet i Tromsø, 2010a, 2010b). En kvalitativ studie viser imidlertid at studentene ikke arbeider med elever med spesielle behov i praksisperiodene (Sørensen, 2019). 
En viktig forskjell mellom denne utprøvingen og den nye nasjonale GLU master er at UiT-studentene i 1-7 skrev masteroppgave i profesjonsfaget (pedagogikk og elevkunnskap, PEL, i ny utdanning). Ifølge forskriftene til den nasjonale utdanningen som startet i 2017 (Kunnskapsdepartementet, 2016a, 2016b) kan studentene skrive masteroppgave i undervisningsfag, profesjonsrettet pedagogikk eller spesialpedagogikk. Ved UiT tilbys ikke GLU-studentene mulighet til å skrive masteroppgave i spesialpedagogikk. Det er derfor en kritikk mot vår case at spesialpedagogikk ikke har vært et fagtilbud til studentene som utgjør vårt utvalg. Ved andre utdanningsinstitusjoner, som for eksempel OsloMet - Storbyuniversitetet, er dette tilbudt som et valg, men da vil studentene få ett undervisningsfag færre i utdanningen.

\section{Undersøkelsesopplegg og utvalg}

I datainnsamlingen benyttet vi semistrukturert intervju siden denne formen både gir retning på intervjuet og åpner for å forfølge initiativ og innspill fra informanten som ligger utenfor det opprinnelige fokus i intervjuguiden (Kvale, 2008). Forskeren kunne i løpet av intervjuet stille oppfølgningsspørsmål som ikke var tenkt ut på forhånd. Spørsmålene omhandlet oppfatninger før yrkesstart og hvorvidt de samsvarte med erfaringer etter ett år i yrket. Intervjuguiden inneholdt ikke spørsmål direkte knyttet til spesialpedagogikk. De nyutdannede lærerne fremhevet likevel temaet på eget initiativ når de ble spurt om utfordringer i møte med elever og foresatte og om relevansen av kompetansen fra utdanningen for å løse arbeidsoppgavene i skolen. Informantene fremsto generelt som oppriktige og var både positive og kritiske til utdanningen og til deres arbeid i skolene.

Informantene i denne studien kommer fra tre kull. Totalt 43 personer, fordelt på 29 kvinner og 14 menn, ble intervjuet rett etter fullført utdanning, 29 av informantene ble igjen intervjuet etter ett år i yrket, mens 17 også ble intervjuet etter to år i yrket. Valget av informanter er basert på et strategisk utvalg (Thagaard, 2006), og de har selv valgt å delta basert på en skriftlig invitasjon og informasjon fra forskerteamet. I hovedsak arbeider informantene i Nord-Norge, men en fjerdedel arbeider i landet for øvrig. Hvert intervju varte i ca. en time og ble transkribert av en forskningsassistent. I transkripsjonen er det vektlagt en mest mulig korrekt gjengivelse av lærernes utsagn. Intervjuene foregikk både på lærernes arbeidssted, på universitetet og av praktiske årsaker via Skype og telefon.

\section{Analyse}

Datamaterialet ble analysert ved hjelp av en temasentrert analysestrategi (Thagaard, 2006) og dataverktøyet NVivo12. Analysen tok først utgangspunkt i temaer som lærerne snakket om og var opptatt av. Allerede i intervjuene og i analyseprosessen oppdaget forskerne at de nyutdannede uttalte at spesialpedagogikk var en utfordring. Vi samlet derfor alle utsagn om spesialpedagogikk fra først 35 intervjuer i én node eller «Bucket codes» i NVivo12 (Bazeley, 2007). For å identifisere alle utsagn i et så omfattende materiale gjennomførte vi tekstsøk i 
NVivo 12 på ordene «Spes ped», «spesialpedagogikk», «PPT», «ADHD», «autisme», «IOP» og «tilpasset opplæring». Gjennom disse søkene registrerte vi utsagn om temaene i totalt 23 intervjuer med totalt 43 tekstsekvenser. Vi leste så igjennom alle disse tekstsekvensene og omkringliggende tekst fra de transkriberte intervjuene i NVivo12 og rekodet dem i elleve koder som inneholdt mer enn ett sitat. Ved å lese både foran og etter de søkte ordene sikret vi at vi hadde forstått konteksten som utsagnet ble presentert i. Vi gjennomførte så det samme tekstsøket for de gjenværende 54 intervjuene og fikk treff i 34 intervjuer. Vi leste så igjennom resultatene og konkluderte med at de samsvarte med den første kodingen. Til slutt så vi etter likheter og ulikheter i kodene og oppsummerte følgende kategorier som ble trukket frem av de nyutdannede lærerne: kompetanse om spesialpedagogikk mangler i lærerutdanningen, utfordringer og muligheter for å planlegge og gjennomføre TPO, erfaringsbasert tilnærming og støtteapparatet, og til slutt «et kjemperart system» med kunnskapsutfordringer. Disse kategoriene utdypes i resultatdelen. Sitatene vi har valgt ut, er hentet fra hele materialet og er representative og beskrivende for funnene våre. Sitatene synliggjør transparens i analysen.

To av forskerne, Antonsen og Maxwell, har gjennomført analysene i NVivo12, mens Bjørndal og Jakhelln har gjennomført intervjuene. A ha vært to forskere i arbeidet med analysene, som også har diskutert funnene med intervjueren, har bidratt til forskertriangulering. Artikkelens fire forfattere er alle ansatt ved UiT. Antonsen og Maxwell har ikke tilknytning til lærerutdanningene. Bjørndal og Jakhelln underviser i profesjonsfaget i begge programmene og har veiledet totalt fire av utvalgets studenter på masteroppgaven. I analysen har vi vært bevisste på at vi kan være lojale mot informantene og være ukritiske til deres uttalelser, som er en kjent utfordring ved å forske på egne lærerstudenter (Haug, 2010). I studien har vi fulgt nasjonale forskningsetiske retningslinjer utgitt av NESH (Den nasjonale forskningsetiske komité for samfunnsvitenskap og humaniora). Studien er godkjent av NSD (Norsk samfunnsvitenskapelig datatjeneste) med prosjektnummer 43315. For videre beskrivelse av utfordringer med nærhet mellom forskere og studenter, samt etikk, se metodedelen i Jakhelln et al. (2016) og Bjørndal, Antonsen og Jakhelln (2020) i dette nummeret.

\section{Resultater}

\section{Kompetanse om spesialpedagogikk mangler i lærerutdanningen}

De nyutdannede lærerne uttalte at de mestret å legge til rette for undervisning til de fleste elevene i sine fag fra lærerutdanningen, noe som også er redegjort for i en annen artikkel (Bjørndal et al., 2020). De nyutdannede uttrykte, både etter ferdigstillelse av utdanningen og etter ett og to år, at de manglet spesialpedagogisk kompetanse på flere områder for å utføre sine arbeidsoppgaver relatert til funksjonene som faglærer og kontaktlærer og i spesialundervisning. Arbeidsoppgaver 
hvor de nyutdannede mente at de trengte spesialpedagogisk kompetanse, var for eksempel planlegging og gjennomføring av undervisning, skole-hjem-samarbeid, samarbeid med støtteapparat som Pedagogisk-psykologisk tjeneste (PPT), rapportskriving og IOP. Mange av de nyutdannede ble satt til spesialundervisning som en del av sin stilling. Enkeltlærere tok derfor spesialpedagogisk utdanning, i tillegg til lærerutdanning, for å dekke kunnskaps- og ferdighetsgapet. Av konkrete utfordringer nevnte de nyutdannede utfordringer med å tilpasse undervisningen for elever med autismespekterforstyrrelser og ADHD og å håndtere sosiale utfordringer. De følgende sitatene illustrerer behovene for spesialpedagogisk kompetanse i utdanningen:

\section{L23, 1-7-lærer i barneskolen etter ett år i yrket:}

Det er et gap der. Egentlig er det fagdidaktikken - jeg har tenkt mange ganger på at «herre min dag, vi skulle hatt mer av det på slutten». Kanskje bakt inn i ei sånn spes.ped.-rettet, TPO og mer sånn grundigere forståelse på fagdidaktikk i forhold til ulike elevgrupper. For det kjente jeg meg veldig usikker på - naken i forhold til å ha noe å planlegge [utydelig] kunnskap.

L1, 5-10-lærer i ungdomsskolen etter to år i yrket:

Jeg reflekterer ofte over hvor lite fokus det var på autismespekterforstyrrelser og andre vanlige diagnoser man garantert møter i skolen i utdannelsen. I løpet av min nåværende arbeidsuke er jeg sammen med totalt fem barn med autisme / Aspergers syndrom. Disse elevene har man jo også ansvar for i klasserommet, som faglærer/kontaktlærer.

L10, 5-10-lærer i ungdomsskolen etter ett år i yrket:

Jeg skulle ønske vi hadde lært litt mer om krisesituasjoner på lærerskolen, de her sosiale utfordringene. Og konkret hvordan man håndterer dem, ikke bare lese om ADHD og spiseforstyrrelser, men hva gjør man i skolen? Hvem skal jeg kontakte, hvordan skal jeg prate litt med dem? Du har den sosiale biten. Ja, du har helsesøster, du har sosiallærer, men som lærer er du en person i livet deres. Og for noen er du en av dem de ser mest som voksenpersoner.

Som sitatene synliggjør, etterspurte de nye lærerne konkret kunnskap om spesialpedagogikk for å arbeide med TPO i praksis. For å kunne fremme TPO var det også behov for å håndtere ulike atferdsutfordringer grunnet i motivasjonssvikt, psykologi, sosialt samspill, uro og konflikter i klasserommet. De nyutdannede følte at de manglet kunnskap og kompetanse til å håndtere disse atferdsutfordringene, som derfor kunne ta stor plass i den daglige undervisningen. De nyutdannede uttrykte også at kunnskap om å skrive IOP-er til PPT og rapporter relatert til spesialundervisning burde hatt større fokus i lærerutdanningen. Lærerne etterspurte dessuten kunnskap om samarbeid med støtteapparat som PPT, Barne- og ungdomspsykiatrisk poliklinikk (BUP) og barnevern, noe også L12 understreker:

L12, 1-7-lærer i barneskolen etter to år i yrket:

Nå har jeg noen elever i klassen som vi gjerne ønsker å melde til BUP, men fikk avslag der for det var visst ikke alvorlig nok, og sant, hvordan går man videre på den måten? [...] hvordan samarbeider man med de [PPT], altså det skjemaet der det er for å få 
kontakt med de der, og så er det de pedagogiske rapportene nå som skal inn, en ny mal på det, også IOP og de som ikke skal ha IOP - hvordan melder man de opp til ny IOP, hvordan melder man de av IOP, og så det er jo rapporter i hytt og pine.

Lærerne etterspør ikke spesialpedagogisk kompetanse, men kunnskap som gjør læreren trygg på gjennomføring av sine oppgaver. Sitatet fra L12 uttrykker en frustrerende arbeidssituasjon og en fortvilelse over å ikke strekke til. Sitatet uttrykker også manglende systemstøtte både på egen skole og fra samarbeidende støttestrukturer. Andre informanter erfarte god systemstøtte på egen skole som var til hjelp i både å planlegge og å gjennomføre TPO og for å skrive gode IOPer.

\section{Utfordringer og muligheter for å planlegge og gjennomføre TPO}

De nyutdannedes utfordringer med å gjennomføre TPO i praksis var relatert både til planlegging og gjennomføring av vanlig undervisning og til spesialpedagogisk undervisning i mindre grupper. Utfordringene var knyttet til oppfølgning av både elevene med særskilte behov og de andre elevene. Store klasser og en variert elevgruppe reduserte mulighetene for å se hver enkelt elev. I tilfeller hvor de måtte prioritere elever som trengte mer oppfølgning, ble resten av klassen overlatt til seg selv. Nyutdannedes utfordringer og muligheter for TPO er uttrykt i følgende sitater:

L30, 5-10-lærer i barneskolen etter ett år i yrket:

Ja, det jeg tenker er spesielt utfordrende, er alt jeg tenker at undervisninga ikke bør være ... Men så kjenner jeg likevel det presset og at foreldre nesten kan hinte litt om at «nå har dere vært lenge på det temaet og hvordan skal dere komme dere gjennom alt». Rett og slett det å vite hvor veien går videre, når jeg skal gå videre. Liksom sørge for at alle elevene får TPO, det synes jeg er kjempeutfordrende.

L30, 5-10-lærer i barneskolen etter ett år i yrket:

Det er jo med tanke på noen elever, de dyslektikerne og hvordan jeg skal drive undervisning uten å trekke de for mye ut av den ordinære undervisninga, men samtidig ... Det merker jeg er utfordrende [...] jeg føler at det blir lettere nesten nå når vi får flere elever med dysleksidiagnose fordi da kan jeg være støtte for ei lita gruppe i stedet for én elev. For tanken har aldri vært at jeg skal være én til én.

Ifølge sitatene fra L30 er det utfordringer med å fremme TPO i form av å sikre riktig progresjon for alle elevene. Ytre press fra for eksempel foreldre kan forsterke denne usikkerheten til den nyutdannede. Det andre sitatet viser hvordan det å ha flere elever som trenger tett oppfølgning, kan gi muligheter for gruppeundervisning slik at en slipper å ta enkeltelever ut av klassen. Analysen viste også at flere av de nyutdannede evner å arbeide med utfordrende elever og skape gode relasjoner til dem i undervisningen. Det var nyutdannede som lyktes med å få etablert gode regler og løsninger for å redusere uro i klassen. Disse nyutdannede lærerne fant for eksempel strategier for å takle elever med ADHD, som at de fikk gå ut av timen eller legge seg under bordet ved behov. I disse tilfellene brukte de 
nyutdannede lærerne sine egne ideer eller sine kolleger for å få tips om strategier for å kunne gjennomføre TPO. Selv om de nyutdannede mente arbeid med TPO var utfordrende, viste resultatene at de hadde med seg noe fra utdanningen som de kunne oversette og anvende for å fremme TPO i undervisningen.

\section{Erfaringsbasert tilnærming og støtteapparatet}

Analysene viste videre at nyutdannedes læring og utøvelse av spesialpedagogikk og TPO i praksis var basert på en erfaringsbasert tilnærming, enten ved å prøve og feile selv eller ved å spørre kolleger. Utover dette ble også støtteapparatet en god kilde til å få innsikt i verktøy, rapportskriving og pedagogiske ideer. Følgende sitater oppsummerer den erfaringsbaserte læringsstrategien og støtteapparatets betydning:

L28, 5-10-lærer i barneskolen etter ett år i yrket:

Egentlig spør jeg de som sitter på kontoret mitt. Hva gjør jeg i den saken, og hvis ikke de kan svare, det har ikke skjedd enda da, men da vet jeg hvem jeg kunne ha gått til. Kunne gått til rektor eller fagleder.

L13, 5-10-lærer i ungdomsskolen etter to år i yrket:

Det verste er at det også er andre spes.ped.-lærere inne på de samme elevene, og det er ikke satt av noe tid til at vi får koordinert innsatsen vår. Særskilt norsk, som jeg faktisk har formell kompetanse i, går heller ikke bra. Årsaken ligger etter min mening i organiseringen, for særskilt-ressursen blir i større grad satt inn i grupper som buffer mot utagerende atferd istedenfor å organisere språkbad, lese- og samtalegrupper. Jeg strever med å gi disse elevene hva de trenger.

L5, 5-10-lærer i barneskolen etter ett år i yrket:

Ja, og så hadde vi jo sosiallærer, og når det ble for mye for henne, så hadde vi jo et team som kom inn og som veiledet oss alle, og ga oss mål for hva vi skulle ha fokus på til neste gang. Så hun har fått oss til å innføre belønningssystem i klassen og fått elevene til å bestemme hvilke mål vil skal ha, og så får de positiv forsterkning når de har gjort det de skulle gjøre. Så tar vi dem på fersken i å være flinke.

De nyutdannede lærerne uttrykte at de tilegnet seg kunnskap om ulike tiltak og verktøy ut fra det de erfarte som behov og muligheter i det daglige arbeidet. Denne læringen foregikk i møte med kolleger og ledelse på skolen. Samtidig erfarte lærerne at innsatsen rundt elever med særskilte behov ofte ikke var koordinert godt nok verken internt på skolen eller i eksterne støttestrukturer. L13 stilte også spørsmål ved om ressursen til elevene fungerte mer som et tiltak for klasseledelse enn som spesialpedagogisk tilrettelegging for enkeltelever. Flere lærere uttrykte også at de brukte mye tid på å tilrettelegge undervisningen, men at effektene av denne var vanskelig både å se og å måle. De nyutdannede beskrev dermed utfordringer med å lykkes med de ulike pedagogiske tiltakene.

I tillegg til å søke støtte fra kolleger søkte de nyutdannede kunnskap hos støttestrukturer som ressursteam, sosiallærere, PPT, Statlig pedagogisk tjeneste (Statped) og BUP. Muligheten til å få delta på eksterne kurs varierte. Rektors interne prioriteringer på skolene spilte også inn for å få delta på kurs i arbeidstiden. En 
lærer som eksempelvis ikke fikk innvilget kurs om dysleksi av sin daværende rektor, fikk delta da en ny rektor var ansatt.

\section{«Et kjemperart system» med kunnskapsutfordringer}

L5 og L4, som jobbet i henholdsvis barneskolen og ungdomsskolen, inntok ulike posisjoner i møte med ulike elevers behov. Begge synliggjorde hvordan manglende kunnskap ga utfordringer for å utvikle og vurdere aktuelle tiltak.

L5: Ja, jeg har meldt opp mange. Jeg har hatt en som har fătt 13,65 timer i uken med spesialpedagoger og assistent i sjetteklasse, og han hadde ingen diagnose før jeg kom. Intervjueren: Oi! Hva tenker du om det?

L5: Jeg synes det er helt sprøtt. Jeg så jo første uken at han hadde noe.

Int: Selv om du syntes du hadde altfor lite kompetanse i spesialpedagogikk? [latter]

L5: Ja, men jeg har jo jobbet «i omsorgen» siden jeg var 18 år, så har jeg jo jobbet med veldig mye forskjellig. Så han meldte jeg jo opp, snakket med foreldrene og fikk han meldt opp i september. Så har jeg noen som har blitt utredet for dysleksi, jeg har en som holder på å bli utredet for dysleksi nå. Hun var en av de siste jeg meldte opp. Hun var ei av de stille, flinke jentene som jeg ikke så først ...

Int: Men da har du jo gjort en viktig innsats også for enkeltelever.

L5: Ja, det føles godt. Det gjør jo det, men det er jo flere som ... når jeg ser hvor mye systemsvikt når det bare er enkeltmenneske som møter enkeltmenneske - hadde jeg ikke jobbet i omsorgen, så hadde jeg ikke kunnet sett det, antakelig. Da hadde jeg sett at det var et uromoment i klassen.

L5 er fornøyd med å ha fått tilført ressurser til en av sine elever og reagerer på at det ikke har skjedd før. L5 har tidligere i intervjuet sagt at hun har kjent på at hun manglet kompetanse i spesialpedagogikk. Når kunnskapsbehovet ble påtrengende, tydde hun til tidligere erfaringer fra arbeid i helsevesenet uten å stille spørsmål ved erfaringenes overførbarhet. For L5 var det viktig å ivareta elever med særlige behov og ikke definere dem som uromomenter. Informanten opplevede også selv mestring når den enkelte fikk ekstern hjelp og tilført ressurser fra PPT. L5 har flere enkeltelever som får hjelp av støttestrukturene. Vi kan ikke utelukke at de meldte casene var reelle, og at dette var riktige strategier for TPO ved den enkelte skole.

L4 hadde også meninger om å «melde til PPT» og signaliserte usikkerhet relatert til hvordan han skulle forholde seg til elever som etter hans vurdering hadde særskilte behov. Han uttrykte behovet for mer kunnskap og undret seg over økningen i diagnoser:

L4, 5-10-lærer i ungdomsskolen etter to år i yrket:

Og så spes.ped.-en, den kunne det vært behov for [i utdanningen]. Og spesielt sånn som nå, det blir jo bare flere og flere som blir meldt inn til PPT og får diagnoser. Da ser jeg enda mer vits i å ha et fag på lærerskolen om det. Hva det var? Vi startet vel fjoråret med 2,5\% av elevene hadde spesialundervisning av et eller annet slag, og så endte vi opp året med 12 \% eller 14 \% eller noe sånt. Og det er jo fordi elevene ikke har vært meldt inn til PPT tidligere. Og jeg snakket med kompiser som jobber i barneskoler rundt omkring, og der er det sånn: «ja, herregud, jeg må melde inn til PPT», «nei, det synes 
jeg ikke ... det her er TPO som skal til», får de beskjed fra ... ofte fra de instansene jeg tar kontakt med. Så er det sånn ... «nei, det er TPO du må jobbe med, det her er ikke noe de trenger å ha en diagnose på». Så kommer de til ungdomsskolene, og så «å, se her ja, nå er det diagnose», så det er et kjemperart system.

L4 forteller om hvordan hans kolleger i barneskolen opplever stor grad av usikkerhet og et uoversiktlig system når det kommer til elevers behov for tilrettelegging. Hans erfaring var at elevene gjerne ikke ble fanget opp før i ungdomsskolen, men at diagnostiseringen da kom for seint.

L4: ... og det å plutselig få slengt et papir på bordet hvor det står at denne eleven må ha IOP, du må skrive det nå. Og så sitter man her og ikke har hatt noe opplæring på det fra lærerskolen, altså [utydelig: enn] IOP - hvordan gjør jeg dette? Og så går man inn på andre sine IOP-er og ser på en slags mal da, «å ja, er det sånn ja», og så prøver man seg fram og så får man beskjed om at «nei, du må fikse på det her».

L4: Ja, jeg kan se for meg at det hadde vært veldig gunstig å sette inn et ordentlig støt på mellomtrinnet, altså på femte til sjuende, for det er da fagstoffet begynner å bli tyngre i de fleste fag. Og det blir flere timer med fag, og så skal de tross alt over på ungdomsskolen der det forventes at de har noen strategier som de kan. Og så skal de i tillegg kunne tilegne seg nye, og hvis de ikke da har muligheten til det, så er det jo ... det er så mye ekstraarbeid. Så det hadde vært fint med en del spesialundervisning i barneskolen.

Avslutningsvis argumenterer L4 for en særlig innsats på mellomtrinnet og knytter argumentasjonen til fagdidaktisk kunnskap. Også L4 søkte til ulike kanter for å forstå det han erfarte. Samtidig viste han en forventning til trinnene under, her barneskolen. Lærerne oppfattet systemet som uryddig og uklart når det kom til TPO og håndtering av elevers ulikhet. De nyutdannede i studien mente de var godt skolert i organisasjon og endring, men det å kunne se enkeltelevene, spesielt de som trengte særskilt tilrettelegging, var utfordrende i yrkesutøvelsen.

\section{Diskusjon}

Resultatene viser at de nyutdannede lærerne mangler spesialpedagogisk kunnskap og ferdigheter for å arbeide med atferdsproblemer og bestemte diagnosegrupper for å fremme et inkluderende læringsmiljø for alle elevene i klassen. De nyutdannede lærerne uttrykker også at de mangler kompetanse om hvordan det eksterne støtteapparatet, som for eksempel PPT, fungerer, og hvordan og når de skal melde inn behov for tiltak. Lærerne opplever utfordringer med å fremme TPO for en variert elevgruppe, spesielt relatert til elever med behov for særskilt tilrettelegging.

Enkelte nyutdannede innhenter kunnskap selv ved å delta på kurs eller veiledning fra PPT, BUP eller andre relevante aktører som arbeider med tema som IOP-er, diagnoser som Aspergers syndrom, dysleksi og så videre. De nyutdannede synes å forvente av seg selv at de skal kunne søke ny kunnskap der de erfarer 
kunnskapshull. De nyutdannede tilegner seg spesialpedagogisk lærerkompetanse ved en erfaringsbasert tilnærming. De tester egne ideer eller følger råd fra kolleger. Enkelte nyutdannede uttaler at systematisk støtte på egne skoler og støtteapparat fremmet mestring innenfor det spesialpedagogiske feltet og TPO. I analysen ser vi at det varierer tilfeldig hvilke hjelperessurser de nyutdannede har tilgjengelig fra kommuner og skoler. Siden de må innhente kunnskap fra kolleger eller systemet, kan dette resultere i at de arbeider ukritisk i tråd med etablert praksis. Slik kan en praksis som ikke fungerer optimalt, vedlikeholdes (Nordahl et al., 2018).

Resultatene fra analysen kan også forklares ved at lærerutdanningsprogrammene ved UiT fra 2010 til 2017 ikke ga studentene tilstrekkelig spesialpedagogisk kunnskap og ferdigheter. I denne lærerutdanningen var spesialpedagogikk og TPO lagt til andre året i utdanningen. Sisteinntrykket er gjerne det som fester seg best i vår hukommelse (Kirschner, Sweller \& Clark, 2006). Designet kan dermed utilsiktet ha hatt som effekt at studentene har glemt denne kunnskapen. En annen mulig forklaring på manglende spesialpedagogikk i lærerutdanningen ved UiT kan være liten kontakt og manglende samlokalisering mellom spesialpedagogiske fagmiljøer og lærerutdannere. Studier viser at samlokalisering kan fremme samarbeid mellom ulike fagmiljøer (Antonsen \& Ellingsen, 2019). Våre resultater indikerer at det kan stilles spørsmål ved hvordan den nye nasjonale GLU håndterer TPO og spesialpedagogisk kunnskap og ferdigheter. GLU har et stort fagfokus, mens fagfeltet spesialpedagogikk har et lite omfang for de av studentene som ikke skriver masteroppgave i spesialpedagogikk (Kunnskapsdepartementet, 2016a, 2016b).

De nyutdannede lærerne etterspør konkrete løsninger og oppskrifter for å kunne planlegge, gjennomføre og rapportere om særskilt tilrettelegging for elever.

De nyutdannedes erfaringer med spesialpedagogikk og TPO samsvarer med argumentasjonen til Nordahl et al. (2018). Den inkluderende pedagogiske tilnærmingen til Florian og Spratt (2013) indikerer at de nyutdannede lærerne selv må gjøre bevisste valg ut over de erfaringsbaserte tilnærmingene. Lærernes fortrinn som observatører og tilretteleggere for elevenes læring utnyttes ikke når det gjelder spesialpedagogikk. Vårt bidrag fra denne studien er at de nyutdannede trenger mer kunnskap og ferdigheter om TPO og relasjonell tenkning i sin lærerkompetanse fra utdanningen. Det må være et mål med en forskningsbasert lærerutdanning at lærerne kan stille spørsmål, reflektere og være med i vurdering av tiltak og utvikle en inkluderende pedagogikk i tråd med Florian og Spratt (2013).

De nyutdannede kan ikke lære alt gjennom lærerutdanningen. Nyutdannede lærere er ofte i en sårbar situasjon i yrkesstarten på bakgrunn av gapet mellom utdanningen og den komplekse arbeidssituasjonen (Caspersen \& Raaen, 2014). Det er et dilemma at tilegnelse av spesialpedagogiske kunnskaper og ferdigheter i yrkesstarten kan øke arbeidsbelastningen for de nyutdannede. Byråkratiske utfordringer som de nyutdannede må tilegne seg ved å skrive rapporter og håndtere støtteapparatet, kan i verste fall bli en faktor som bidrar til at de vurderer å gå 
ut av yrket. Vi vil argumentere for at kunnskap om relasjonell tenkning om TPO og spesialpedagogikk kan hjelpe de nyutdannede til å håndtere ulike elevutfordringer. Lærere med en relasjonell tenkning om inkludering og TPO kan bidra til utvikling av arbeidet med TPO og spesialpedagogikk (Dalkilic \& Vadeboncoeur, 2016).

Denne RELEMAST-studien var ikke opprinnelig designet som en studie av spesialpedagogiske utfordringer i skolen og hadde ikke spesialpedagogikk som sentralt fokus i intervjuguiden. En kritikk mot våre resultater kan være at de kritiske stemmene om spesialpedagogikk har vært i overtall fordi disse kom frem i forbindelse med åpne spørsmål om utfordringer i yrkesstarten. De lærerne som har opplevd å mestre spesialpedagogikk, har ikke blitt spurt direkte om dette og kan naturligvis ha unnlatt å nevne det. Med denne potensielle skjevheten i datamaterialet gir vi derfor en advarsel mot generaliseringer av resultatene fra denne studien. Vi har heller ikke intervjuet informanter eller undersøkt læreplaner fra andre lærerutdanninger i Norge.

\section{Konklusjon}

I denne studien har vi undersøkt hvordan nyutdannede grunnskolelærere erfarer at lærerkompetansen fra en integrert femårig grunnskolelærerutdanning samsvarer med deres behov for kunnskap om spesialpedagogikk og TPO i yrkesstarten.

Resultatene viser at de nyutdannede lærerne etterspør kunnskap om og ferdigheter relatert til å arbeide med ulike atferdsproblemer og bestemte diagnosegrupper. Lærerne uttrykte også usikkerhet om hvordan det eksterne spesialpedagogiske støtteapparatet fungerer, og hvordan og når de skal melde inn tiltak. Enkelte nyutdannede i arbeid får tilegnet seg kompetanse ved å delta på kurs eller veiledning fra PPT, BUP eller andre aktører om temaer som IOP-er eller diagnoser.

I sitt arbeid opplevde de nyutdannede lærerne utfordringer med å tilpasse opplæringen for en sammensatt elevgruppe, spesielt for elever med behov for særskilt tilrettelegging. De nyutdannedes mangel på relevant kunnskap fra lærerutdanningen gjør at arbeidet med spesialpedagogikk og utfordringer med TPO løses basert på egne erfaringer eller kollegers råd og erfaringer. Denne erfaringsbaserte spesialpedagogiske tenkningen og praksisen samsvarer ikke med intensjonene om å utdanne lærere som arbeider forsknings- og kunnskapsbasert. Basert på våre resultater argumenterer vi for å fremme mer relasjonell tenkning og inkluderende pedagogikk i GLU.

Det er behov for å undersøke nyutdannede læreres muligheter for å tilegne seg lærerkompetanse for arbeid med spesialpedagogiske spørsmål de første årene i yrket. Det er også behov for å studere ulike lærerutdanningers studieplaner og intervjue lærerstudenter som har studert ved andre læresteder for å få et bredere 
bilde av utfordringer og mulige løsninger. Det er et potensial for å utarbeide en kvalitativ spørreundersøkelse for hele landet og internasjonalt både til lærerutdannere og til nye lærere for å validere resultatene i denne studien. I vår studie har vi heller ikke spurt om spesialpedagogiske utfordringer relatert til nyutdannedes møte med elever med stort læringspotensial, minoriteter, urfolk eller innvandrergrupper. Våre resultater tilsier at det kan være grunn til å forske mer på spesialpedagogikkens og spesialpedagogers plass i den norske GLU og i internasjonal sammenheng. Det er også behov for å forske videre på å utvikle og utprøve relasjonell tenkning i lærerutdanningen og utdanningssystemet.

\section{Om forfatterne}

Yngve Antonsen er førsteamanuensis i pedagogikk. Hans forskningsinteresser omfatter ledelse, endring og læring i organisasjoner. Han leder RELEMASTprosjektet.

Institusjonstilknytning: Institutt for lærerutdanning og pedagogikk, UiT Norges arktiske universitet, Postboks 6050 Langnes, 9037 Tromsø.

E-post: yngve.antonsen@uit.no

Gregor Maxwell er førsteamanuensis i spesialpedagogikk. Hans forskningsinteresser omfatter inkludering, deltakelse og utdanningspolitikk. Han deltar i RELEMAST-prosjektet.

Institusjonstilknytning: Institutt for lærerutdanning og pedagogikk, UiT Norges arktiske universitet, Postboks 6050 Langnes, 9037 Tromsø.

E-post: gregor.maxwell@uit.no

Kristin Emilie Willumsen Bjørndal er førsteamanuensis i pedagogikk. Hennes forskningsinteresser omfatter blant annet nyutdannede lærere, filosofering med barn og digital dømmekraft. Hun deltar i forskningsprosjektet RELEMAST. Institusjonstilknytning: Institutt for lærerutdanning og pedagogikk, UiT Norges arktiske universitet, Postboks 6050 Langnes, 9037 Tromsø.

E-post: kristin.e.bjorndal@uit.no

Rachel Jakhelln er professor i pedagogikk. Hennes forskningsinteresser er nyutdannede lærere, lærerutdanning og utdanningens praksis, overgangen fra utdanning til yrke og profesjonskunnskap. Hun er initiativtaker til RELEMASTprosjektet.

Institusjonstilknytning: Institutt for lærerutdanning og pedagogikk, UiT Norges arktiske universitet, Postboks 6050 Langnes, 9037 Tromsø.

E-post: rachel.jakhelln@uit.no 


\section{Forfatterbidrag}

Alle forfatterne har bidratt til artikkelen i henhold til Vancouver-reglene. Alle har lest igjennom og godkjent artikkelen. Forfatterne har bidratt spesielt i disse fasene av artikkelskrivingen:

Yngve Antonsen med analyse, innledning, presentasjon av empiri, diskusjon og avslutning.

Gregor Maxwell med analyse, presentasjon av empiri, forskning og teoretisk rammeverk, diskusjon og avslutning.

Kristin Emilie Willumsen Bjørndal med studiens etablering, datainnsamling, analyse og diskusjon.

Rachel Jakhelln med studiens etablering, datainnsamling, analyse og diskusjon.

\section{Referanser}

Antonsen, Y. \& Ellingsen, M.-B. (2019). Samlokalisering av nødmeldingssentralene til politi, brann og helse utvider praksisfellesskapet og læring om samvirke. Nordisk politiforskning, 6(1), 46-64. https://doi.org/10.18261/issn.1894-8693-2019-01-05

Aspelin, J. (2014). Beyond individualised teaching. Education Inquiry, 5(2), 233-245. https://doi.org/10.3402/edui.v5.23926

Bachmann, K. \& Haug, P. (2006). Forskning om tilpasset oppløring. Volda: Høgskulen i Volda.

Bakke, J. (2011). Spesialpedagogikk i klassesamfunnet. Norsk pedagogisk tidsskrift, 95(2), $141-154$.

Bakke, J. (2017). Tilpasset opplæring i skole og samfunn. I V. D. Haugen \& G. Stølen (red.), Pedagogisk mangfold : $i$ et samfunnsperspektiv (s. 146-164). Oslo: Universitetsforlaget.

Bazeley, P. (2007). Qualitative Data Analysis with NVivo. Los Angeles, CA: Sage Publications.

Bjørndal, K. E. W., Antonsen, Y. \& Jakhelln, R. (2020). FoU-kompetansen til nyutdannede grunnskolelærere - grunnlag for skoleutvikling? Acta Didactica Norden, 14(2), Art. 7. http://dx.doi.org/10.5617/adno.6971

Brekke, M., Bjarnadóttir, R. \& Søndenå, K. (2008). Teacher education didactics in the north En introduksjon av hovedprosjekt og første fase. I R. Bjarnadóttir, M. Brekke, I.

Karlefors, P. Nielsen \& K. Søndenå (red.), LAERERLIV sett med nordiske studentøyne (bd. 1, s. 7-17). Tromsø: Eureka Forlag.

Cardona Moltó, M. C. (2009). Teacher Education Students’ Beliefs of Inclusion and Perceived Competence to Teach Students with Disabilities in Spain. Journal of the International Association of Special Education, 10(1), 33-41. http://hdl.handle.net/10045/24899

Caspersen, J. \& Raaen, F. D. (2014). Novice teachers and how they cope. Teachers and Teaching, 20(2), 189-211. https://doi.org/10.1080/13540602.2013.848570

Crotty, M. (1998). The foundations of social research: Meaning and perspective in the research process. Thousand Oaks: Sage.

Dalkilic, M. \& Vadeboncoeur, J. A. (2016). Re-framing inclusive education through the capability approach: An elaboration of the model of relational inclusion. Global Education Review, 3(3), 122-137. 
Fasting, R. B. (2013). Adapted education: the Norwegian pathway to inclusive and efficient education. International Journal of Inclusive Education, 17(3), 263-276. https://doi.org/10.1080/13603116.2012.676083

Fasting, R., Sarromaa Hausstätter, R. \& Turmo, A. (2011). Inkludering og tilpasset opplæring for de utvalgte? Norsk pedagogisk tidsskrift, 95(2), 85-90. http://www.idunn.no/npt/2011/02/art03

Flem, A. \& Keller, C. (2000). Inclusion in Norway: a study of ideology in practice. European Journal of Special Needs Education, 15(2), 188-205. https://doi.org/10.1080/088562500361619

Florian, L., Hawkins, K. B. \& Rouse, M. (2017). Achievement and Inclusion in Schools. London: Routledge.

Florian, L. \& Spratt, J. (2013). Enacting inclusion: a framework for interrogating inclusive practice. European Journal of Special Needs Education, 28(2), 119-135. https://doi.org/10.1080/08856257.2013.778111

Gjessing, H. J. (1967). Spesialundervisningens personellbehov. Oslo: Statens spesiallærerskole.

Haug, P. (2010). Kvalifisering til læraryrket. I P. Haug (red.), Kvalifisering til læraryrket (s. 9-28). Oslo: Abstrakt forlag.

Haug, P. (2004). 65 år med tilpassa opplæring i grunnskulen. I P. Hamre, O. Langlo, O. Monsson \& H. Osdal (red.), Fag og fagnad : festskrift til Kjell-Arild Madssen i høve 60årsdagen (s. 62-81). Volda: Høgskulen i Volda.

Jakhelln, R. E., Bjørndal, K. E. \& Stølen, G. (2016). Masteroppgaven - relevant for grunnskolelæreren? Acta Didactica Norge, 10(2), 193-211. https://doi.org/10.5617/adno.2454

Jenssen, E. S. \& Lillejord, S. (2009). Tilpasset opplæring: politisk dragkamp om pedagogisk praksis. Acta Didactica Norge, 3(1), Art. 13. Hentet fra http://hdl.handle.net/1956/5726

Kirschner, P. A., Sweller, J. \& Clark, R. E. (2006). Why minimal guidance during instruction does not work: An analysis of the failure of constructivist, discovery, problem-based, experiential, and inquiry-based teaching. Educational psychologist, 41(2), 75-86.

Kunnskapsdepartementet (2016a). Forskrift om rammeplan for grunnskolelcererutdanning for trinn 1-7. Oslo: Regjeringen. Hentet fra https://lovdata.no/dokument/SF/forskrift/2016$\underline{06-07-860}$

Kunnskapsdepartementet (2016b). Forskrift om rammeplan for grunnskolelcererutdanning for trinn 5-10. Oslo: Regjeringen. Hentet fra https://lovdata.no/dokument/SF/forskrift/201606-07-861

Kvale, S. (2008). Det kvalitative forskningsintervju (11. utg.). Oslo: Gyldendal Akademisk.

Markussen, E., Strømstad, M., Carlsten, T. C., Hausstätter, R. \& Nordahl, T. (2007). Inkluderende spesialundervisning? Om utfordringer innenfor spesialundervisningen $i$ 2007 (Rapport nr. 1 fra prosjektet: Gjennomgang av Spesialundervisning, Evaluering av Kunnskapsløftet). NIFU STEP-rapport 19-2007. Høgskolen i Hedmark og NIFU STEP. Hentet fra http://hdl.handle.net/11250/279073

Maxwell, G. (2017). Perspectives in Inclusion and Special Eduction. I V. D. Haugen \& G. Stølen (red.), Pedagogisk mangfold : i et samfunnsperspektiv (s. 165-187). Oslo: Universitetsforlaget.

Mordal, K. N. \& Strømstad, M. (2005). Norway: adapted education for all? I M. Ainscow \& T. Booth (red.), From them to us (s. 108-124). London: Routledge.

Nordahl, T., Persson, B., Brørup Dyssegaard, C., Wessel Hennestad, B., Vaage Wang, M., Martinsen, J., ... Johnsen, T. (2018). Inkluderende fellesskap for barn og unge: Ekspertgruppen for barn og unge med behov for scrskilt tilrettelegging. Bergen: Fagbokforlaget.

NOU (2003:16). I første rekke: Forsterket kvalitet i en grunnopplcring for alle. Oslo: Statens forvaltningstjeneste. Hentet fra 
https://www.regjeringen.no/contentassets/37a02a7bd6d94f5aacd8b477a3a956f3/no/pdfs/n ou200320030016000dddpdfs.pdf

OECD (2019). Education at a Glance 2019. Paris: OECD Publishing. https://doi.org/10.1787/f8d7880d-en.

Opplæringslova (1998). Lov om grunnskolen og den vidaregåande oppleringa. LOV-199807-17-61. Hentet fra https://lovdata.no/dokument/NL/lov/1998-07-17-61

Riksrevisjonen (2006). Riksrevisjonens undersøkelse av opplæringen i grunnskolen. Dokument nr. 3:10 (2005-2006). Oslo: Riksrevisjonen. Hentet fra https://www.stortinget.no/globalassets/pdf/dokumentserien/20052006/dok_3_10_2005_2006.pdf

Skogen, K. (2014). "Ekspertene" har talt: anbefalinger fra ekspertgruppe for spesialpedagogikk. Bedre skole, (3), 84-87.

Statistisk sentralbyrå (2019). Fakta om utdanning: nøkkeltall fra 2017. Oslo: Seksjon for utdannings- og kulturstatistikk, Statistisk sentralbyrå.

Sætra, E. (2018). Om forholdet mellom teori og praksis i lærerutdanning. Norsk pedagogisk tidsskrift, 102(4), 340-350. https://doi.org/10.18261/issn.1504-2987-2018-04-05

Sørensen, Y. (2019). A gripe og bli grepet - for å begripe. Lcererstudenters opplevelse av praksisopplæringen og dens betydning for profesjonell utvikling. Doktoravhandling, UiT Norges arktiske universitet, Tromsø. Hentet fra https://munin.uit.no/bitstream/handle/10037/14947/thesis.pdf?sequence=2\&isAllowed=y

Thagaard, T. (2006). Systematikk og innlevelse: En innføring i kvalitativ metode (2. utg.). Bergen: Fagbokforlaget.

Universitetet i Tromsø (2010a). Studieplan for integrert mastergradsprogram leererutdanning 5.-10. trinn (Kull 2013-2016).

Universitetet i Tromsø (2010b). Studieplan for integrert mastergradsprogram læererutdanning 1.-7. trinn (Kull 2013-2016).

Uthus, M. (2018). Spesialpedagogikk for morgendagens skole - nye mål og ny mening. Spesialpedagogikk, (4), 17-24. Hentet fra https://www.utdanningsnytt.no/files/2019/10/03/Spesialpedagogikk\%20nr\%204\%202018. pdf

Velsvik Bele, I. (2010). Læreres egenvurdering av spesialpedagogisk kompetanse - og viktige kilder for kompetanseutvikling. Norsk pedagogisk tidsskrift, 94(06), 476-491. Hentet fra http://www.idunn.no/npt/2010/06/art04 